Historia Slavorum Occidentis

2019, $\mathrm{nr} 4$ (23)

ISSN 2084-1213

DOI: $10.15804 /$ hso190404

Tomasz Sikorski (Szczecin)

Urszula KoZłowska (SzCZecin)

\title{
Kooperacja w sporcie wyczynowym w krajach bloku wschodniego na przykładzie kontaktów polsko-rumuńskich (1948-1953)
}

Słowa kluczowe: sport, relacje polsko-rumuńskie, Blok wschodni, komunizm, kooperacja w sporcie

Keywords: sport, Polish-Romanian relations, Eastern Bloc, communism, cooperation in sport

Abstract: The authors of the article carried out an analysis of sports contacts between Poland and Romania in the time of Stalinism by taking into account the ideological and organisational changes in both countries' sport as well as sport rivalry. Of importance was also presenting the implementation of the Soviet model of physical culture in Poland and Romania coupled with difficulties and barriers to sports cooperation between Poland and Romania.

W państwach znajdujących się pod ścisłą kontrolą Moskwy praktycznie już od 1945 r. wdrażano sowiecki, instytucjonalny model organizacji kultury fizycznej. W 1945 r. na czele radzieckiego Wszechzwiązkowego Komitetu Kultury Fizycznej i Spraw Sportowych stanął Nikołaj Romanow. Rozpoczęto wówczas kolejną już czystkę w środowisku sportowym, wzmocniono pozycję milicyjnych i wojskowych klubów resortowych, ale także umiędzynarodowiono radziecki sport poprzez wprowadzenie sportowców wyczynowych na areny światowe. W latach 1948-1953 Komitet doprowadził do całkowitej centralizacji i ideologizacji sportu wyczynowego 
i wypoczynku. Po śmierci Józefa Stalina - w 1953 r. Wszechzwiązkowy Komitet Kultury Fizycznej i Spraw Sportowych został przekształcony w Główny Zarząd Kultury Fizycznej i Sportu. Formalnie był on podporządkowany Ministerstwu Zdrowia, ale $\mathrm{w}$ praktyce najważniejsze decyzje dotyczące sportu podejmowano w wąskim gremium Biura Politycznego i Sekretariacie KC KPZR².

W interesującym nas okresie, tj. w latach 1948-1953 r., we wszystkich państwach bloku wschodniego wprowadzono niemal identyczne wzorce organizacji sportu. W Polsce, względny pluralizm na płaszczyźnie koncepcyjnej (i organizacyjnej) zniknął w momencie umocnienia się pozycji PPR, po sfałszowanych wyborach do Sejmu w styczniu 1947 r. W konsekwencji już w wiosną 1947 r. rozpoczęto prace nad projektem reorganizacji struktur zarządzających sportem. W lutym $1948 \mathrm{r}$. na mocy ustawy „O powszechnym obowiązku przysposobienia zawodowego, wychowania fizycznego i przysposobienia wojskowego młodzieży oraz organizacji kultury fizycznej i sportu”, w miejsce Państwowego Urzędu Wychowania Fizycznego i Przysposobienia Wojskowego i Państwowej Rady Wychowania Fizycznego i Przysposobienia Wojskowego powołano nowy centralny urząd, wzorowany na radzieckich doświadczeniach - Główny Urząd Kultury Fizycznej (dalej GUKF), a następnie wojewódzkie urzędy kultury fizycznej oraz powiatowe inspektoraty kultury fizycznej². Bezpośrednim powszechnym kierownictwem nad przysposobieniem obronnym odtąd miała się zająć Powszechna Organizacja „Służba Polsce”, kontrolowana politycznie przez PPR, a następnie PZPR, za pośrednictwem kolejno: ZMW i ZMP³. Stopniowo zdelegalizowano niezależne organizacje sportowe, jak gniazda „Sokoła” i organizację YMCA4.

1 Por szerzej: A. Pasko, Społeczno-polityczne aspekty sportu w ZSRR i krajach bloku socjalistycznego do 1989 roku, Prace Naukowe Akademii im. Jana Dlugosza w Częstochowie. Seria Kultura Fizyczna, z. 10 (2011), s. 117-118; J. Riordan, Sowiet sport. Background to the Olympics, Oxford 1980, s. 163-168.

2 Ustawa z dnia 25 II 1948 r. o powszechnym obowiazku przysposobienia zawodowego, wychowania fizycznego i przysposobienia wojskowego młodzieży oraz organizacji spraw kultury fizycznej i sportu, Dz. U. 1948, nr 12, poz. 90. Zob. również: A. Pasko, Sport wyczynowy w polityce państwa 1944-1989, Kraków 2012, s. 68-80; P. Godlewski, Sowietyzacja sportu $w$ Polsce (1948-1956), [w:] Studia z dziejów kultury fizycznej. Księga Pamiątkowa dla Profesora Bernarda Woltmana, red. T. Jurek, Gorzów Wielkopolski 2002, s. 448-450.

3 Na temat działalności „SP” zob. szerzej: K. Lesiakowski, Powszechna Organizacja „Stużba Polsce" w latach 1948-1955, Lublin 2006.

4 A. Nowakowski, Zarządzanie kultura fizyczna $w$ Polsce $w$ latach 1944-2001. Studium historyczno-porównawcze, Rzeszów 2005, s. 29, 44; A. Pasko, Likwidacja Towarzystwa Gimnastycznego „Sokót” po 1947 r., [w:] 100-lecie Ogólnopolskiego Zlotu Sokołów w Krakowie 
Rok później „zreorganizowano” AZS organizacje młodzieżowe tworząc Związek Młodzieży Polskiej ${ }^{6}$.

Proces centralizacji sportu wedle radzieckiego wzorca, a zarazem jego propagandowej ideologizacji (w gruncie rzeczy stalinizacji) nabrał tempa po tzw. zjednoczeniu ruchu robotniczego i utworzeniu Polskiej Zjednoczonej Partii Robotniczej (15 XII 1948 r.). Doniosłe znaczenie miała tutaj uchwała Biura Politycznego KC PZPR z 28 IX 1949 r. „W sprawie kultury fizycznej i sportu”, w której podkreślano, że sport i kultura fizyczna są nieodłącznym elementem budowy „podstaw socjalizmu w Polsce Ludowej” oraz wychowania człowieka „świadomego twórcy nowego, sprawiedliwego ustroju". W sprawach organizacyjnych Biuro Polityczne KC PZPR zapowiadało „poddanie kultury fizycznej i sportu jednolitemu, państwowo-społecznemu kierownictwu i kontroli”. Nowo powołany Główny Komitet Kultury Fizycznej przy Radzie Ministrów (GKKF), faktycznie uzależniony od rządzącej partii (Wydział Propagandy i Agitacji KC PZPR) miał odtąd kierować, koordynować i kontrolować kulturę fizyczną i sport, dbać o podniesienie poziomu ideologicznego i „fachowego propagandy”.

W niespełna trzy miesiące po przyjęciu uchwały Biura Politycznego KC PZPR, Sejm uchwalił „Ustawę o organizacji spraw kultury fizycznej i sportu” 7 . Formalnie

- Zlotu Grunwaldzkiego - 100 lecie odstonięcia pomnika Grunwaldzkiego w Krakowie 1910-2010, red. A. Łopata, J. Fall, Kraków 2010, s. 97-104; E. Kałamacka, Działalność polskiej YMCA w dziedzinie wychowania fizycznego i sportu, Wychowanie Fizyczne i Sport 4 (1989), s. 77-90.

5 Por. K. Obodyński, Rola Akademickiego Zwiąku Sportowego w ksztattowaniu się struktur akademickiej kultury fizycznej w latach 1945 - 2005, [w:] Akademicka kultura fizyczna na przetomie stuleci, t. 1: Stan i perspektywa zmian, red. K. Obodyński, Z. Barabasz, Warszawa 2009, s. 8; R. Wryk, Narodziny i rozwój Akademickiego Zwiazku Sportowego do roku 1947, Warszawa 2014, s. 250.

6 Szerzej na temat ZMP pisali mi.in.: M. Wierzbicki, Związek Młodzieży Polskiej i jego członkowie: studium z dziejów funkcjonowania stalinowskiej organizacji młodzieżowej, Warszawa 2006; Idem, Związek Młodzieży Polskiej a rozwój kultury fizycznej w Polsce w okresie stalinowskim (1948-1956), [w:] Magia sportu i stowa. Tom studiów dedykowany Redaktorowi Bohdanowi Tomaszewskiemu, red. A. Dobrowolska, M. Szczerbiński, G. Wieczorek, Gorzów Wielkopolski 2008, s. 101-114.

7 Ustawa $z$ dn. 30 XII 1949 r. o organizacji spraw kultury fizycznej i sportu, [w:] Uchwaty $i$ dokumenty $w$ sprawie kultury fizycznej za rok 1950, Warszawa 1951, s. 17-21. Zob. też: A. Zagórska, A. Nowakowski, Ustawa o kulturze fizyczne w Polsce z 1949 roku, [w:] Z najnowszych dziejów kultury fizycznej w Polsce (1918-1989): zagadnienia dydaktyczne dla studentów pedagogiki $z$ wychowaniem fizycznym oraz historii in honorem Zdzistaw Pawluczuk, red. B. Maksimowski, A. Nowakowski, S. Podobiński, Częstochowa 1999, s. 73-85. 
powołano wówczas do życia GKKF ${ }^{8}$. Wzorując się na doświadczeniach radzieckich przyjęto również system nomenklatury kadr (podobnie jak w innych dziedzinach życia społeczno - gospodarczego), zarówno w centrali, jak i w terenie. Ważne stanowiska w ruchu sportowym obejmowali lojalni wobec PZPR, wyrobieni i uświadomieni ideowo aparatczycy (najczęściej członkowie partii), nierzadko nie mający nic wspólnego z kulturą fizyczną i sportem9

Podobne procesy zachodzily z różną częstotliwością i w różnym tempie w innych krajach demokracji ludowej. Wprowadzenie modelu radzieckiego w poszczególnych państwach przebiegało bardzo podobnie. $\mathrm{Z}$ względnego pluralizmu pierwszych lat powojennych cięciem ideologicznego skalpela zrujnowano przedwojenną tradycję, niezależne związki i organizacje, wyeliminowano znanych, utytułowanych sportowców i działaczy. Włodarzami sportu stali się ludzie związani z komunistyczną partią, nierzadko pozbawieni wiedzy i doświadczenia w sprawach sportu. W konsekwencji postawiono przed całym ruchem sportowym nowe cele i zadania, tworząc swoisty „międzynarodowy front” (polityczny i ideologiczny) umożliwiający współpracę (kooperację), ściśle jednak kontrolowaną i nadzorowaną przez radzieckie kierownictwo partyjne.

W latach 1947-1949 radziecki wzorzec organizacji sportu wprowadzono już we wszystkich państwach bloku wschodniego. Przyjęte rozwiązania „konsultowano” z Kremlem i centralami partii komunistycznych od Pragi po Sofię. W interesującej nas tutaj szczególnie Rumuńskiej Republice Ludowej (Republica Populară Româna) już wiosną 1949 r. (a więc o kilka miesięcy wcześniej aniżeli w Polsce) Biuro Polityczne Rumuńskiej Partii Robotniczej przyjęło uchwałę „w sprawie kultury fizycznej i sportu”.

8 Poprzednikiem GKKF był działający w latach 1948-1949 Główny Urząd Kultury Fizycznej. Założenia organizacyjne związane z funkcjonowaniem GKKF regulowały: Zarządzenie Prezesa Rady Ministrów z dnia 8 II 1950 r. wraz ze zmianami wprowadzonymi Zarządzeniem nr 57 Prezesa Rady Ministrów z dnia 19 III 1951 r. Zob. też: A. Pasko, Sport wyczynowy, s. 114 n.; B. Ryba, Podstawy organizacji kultury fizycznej, Poznań 1989, s. 65- 66; A. Nowakowski, Zarządzanie kultura fizyczna, s. 54-55; L. Szymański, Model zarządzania kultura fizyczna w II Rzeczypospolitej i Polsce Ludowej, Wychowanie Fizyczne i Sport, t. XLI (1997), s. 334; M. Ordyłowski, L. Szymański, Sport w polityce, polityka w sporcie. Stalinizm $w$ Polsce w latach 1949-1956, Człowiek i Ruch 2 (2000), s. 14.

9 Zob. szerzej: A. Pasko, Sport wyczynowy, s. 115 n.; Idem, „Menadżerowie” sportu w Polsce w okresie stalinizmu (1949-1956), Studia Podlaskie, t. XVIII (2009/2010), s. 223-236; P. Godlewski, Sport w Polsce na tle politycznej, s. 265 - 277; M. Ordyłowski, Kadry - „Oko, ucho i ręka" wtadzy ludowej w sporcie polskim 1945 -1989, [w:] Idem, Szkice z dziejów kultury fizycznej, Zielona Góra 2005, s. 181-194. 
Przypominała ona bliźniaczo tekst dokumentu polskiego. Zwracano tam uwagę na potrzebę umasowienia sportu i wypoczynku, wspominano o obciążeniu „burżuazyjną”, „kapitalistyczną” tradycją całego ruchu sportowego. Nawiązywano do wychowania nowego typu sportowca ${ }^{10}$. Utworzono również Komitet do Spraw Kultury Fizycznej i Sportu, a następnie ufundowano odznakę „Gotowy do Pracy i Obrony Kraju” (GMA - „Gata pentru munca si aparare”). Jak informowała „Trybuna Ludu” była to inicjatywa młodych robotników Sovromtractor (fabryka produkująca wówczas ciągniki) w Braszowie (Brașov) ${ }^{11}$. Właściwa postawa ideologiczna i sportowa nagradzana była przez władze partyjne i związki sportowe nie tylko tytułami zasłużonego mistrza sportu, medalami, pucharami, ale również atrakcyjnymi apanażami, jak wczasy w nadmorskich kurortach, rodzinne wyjazdy zagraniczne, talony, bony towarowe, perspektywą otrzymania mieszkania, samochodu, pralki, czy mebli. Cały ruch sportowy został włączony w propagandową machinę, stając się jej nieodłączną częścią. Wprowadzenie nowych rozwiązań kontrolowali w Rumunii, podobnie jak w innych krajach socjalistycznych „etatowi specjaliści” z ZSRR ${ }^{12}$.

Jak już było powiedziane, zasadniczym elementem współpracy „bratnich narodów" była międzynarodowa kooperacja sportowa. Wiązało się to oczywiście z różnego rodzaju problemami związanymi choćby w uzyskaniem paszportu na wyjazd zagraniczny czy przeprowadzeniem personalnej selekcji, tym bardziej że chętnych na udział w zawodach zagranicznych (zwłaszcza w Europie Zachodniej) było najczęściej więcej niż miejsc wyznaczonych przez organy zarządzające sportem. Z drugiej strony udział polskich zawodników w zawodach rangi międzynarodowych, tak samo jak wyjazdy działaczy sportowych na konferencje, sympozja i kongresy, miały poważne znaczenie propagandowe. Podobnie było w przypadku zabiegów o organizacje imprez o międzynarodowej randze. Była to doskonała okazja do promocji kraju, sportu i socjalizmu. Świadczyło też bez wątpienia o pozornej jedynie „normalności” w krajach demokracji ludowej.

Co najmniej do lata 1948 r. władze starały się nie ograniczać międzynarodowych kontaktów sportowych, także z federacjami zachodnioeuropejskimi. Wyjątek sta-

10 Archiwum Akta Nowych [dalej: AAN], Główny Urząd Kultury Fizycznej [dalej: GUKF], sygn. 58, Uchwała Biura Politycznego Rumunskiej Partii Robotniczej w sprawie kultury fizycznej i sportu, k. 75-81.

11 Por. A. Pasko, Spoteczno-polityczne aspekty, s. 121.

12 AAN, KC PZPR, sygn. 237/XXII - 177, Ściśle tajne sprawozdanie z konferencji przedstawicieli Komitetów Kultury Fizycznej ZSRR, Bułgarii, Czechosłowacji, Rumunii, Węgier i Polski, odbytej $w$ Sofii $w$ dniach 19-20 X 1950 r., k. 119. 
nowiły relacje z Japonią, Niemcami zachodnimi i Hiszpanią (jak tłumaczono „faszystowską"), ale trzeba podkreślić, że podobny bojkot zastosowały także niektóre kraje kapitalistyczne, np. skandynawskie. Do końca 1948 r. w urzędowych planach i kalendarzach sportowych nie dzielono państw na: kapitalistyczne i kraje demokracji ludowej. Podział taki wprowadzono dopiero rok później. Można wysunąć tezę, że o kontaktach sportowych z państwami kapitalistycznymi decydowały przede wszystkim dwa względy: możliwości finansowe strony polskiej i korzyści czysto sportowe, a więc zwycięstwa lub dobre wyniki na tle sportowców zachodnioeuropejskich. W każdym razie międzynarodowe kontakty sportowe z Zachodem po 1949 r. (nie licząc olimpiad oraz imprez rangi mistrzowskiej - np. mistrzostwa Europy lub świata) znacznie ograniczono. Tytułem przykładu, w I i II kwartale 1949 r. odbyło się 36 spotkań międzynarodowych w kraju w 15 dyscyplinach, z czego na kraje demokracji ludowej wypadało 657 przyjazdów sportowców, a z krajów kapitalistycznych zaledwie 65 sportowców. W tym samym okresie polscy sportowcy udali się na 44 imprezy zagraniczne, w tym 434 do państw tzw. obozu, a jedynie 55 do Europy Zachodniej ${ }^{13}$. W kolejnych latach proporcje te nie uległy znaczącym wahaniom. Ograniczono jedynie znacząco relacje $\mathrm{z}$ federacjami zachodnioeuropejskimi, niemal wyłącznie do współpracy w ramach imprez rangi mistrzowskiej. Proces ten trwał nieprzerwanie do $1956 \mathrm{r}$.

Za najważniejszą - priorytetową traktowano w latach 1948-1953 kooperację z państwami socjalistycznymi, choć jak się szybko okazało nie wszystkimi. W lutym 1949 r. podczas pierwszej konferencji informacyjno-porozumiewawczej krajów socjalistycznych w Zakopanem, przedstawiciele centralnych organów odpowiedzialnych za zarządzanie sportem uzgodnili, że będą na bieżąco informować poszczególne federacje państw demokracji ludowej o planowanych przedsięwzięciach. Przyjęto również planowany kalendarz najważniejszych, międzynarodowych imprez sportowych na lata 1949-1953 oraz projekt tzw. forum stałych kontaktów międzynarodowych ${ }^{14}$.

13 AAN, GUKF, sygn. 36, Sprawozdanie GUKF z działalności Urzędów Kultury Fizycznej i Sportu za II i II kwartat 1949 r., k. 8; AAN, GUKF, sygn. 70, Notatka w sprawie kontaktów międzynarodowych za rok 1948 i 1949, k. 1 - 3.

14 AAN, GUKF, sygn. 75, Protokót z konferencji informacyjno-porozumiewawczej odbytej $w$ dniu 26 II br. o godzinie 15 w hotelu „Morskie Oko” w Zakopanem, k. 53-60. Od 1951 r. intensywność konferencji kongresów przedstawicieli organów zarządzających sportem w krajach demokracji ludowej znacznie wzrosła. Najczęściej zwoływano je przed imprezami rangi mistrzowskiej lub olimpiadami. 
Sportowcy polscy wzięli udział w Igrzyskach Olimpijskich w Londynie (1948 r.) oraz w odbywających się w tym samym roku Igrzyskach Bałkańskich i Środkowoeuropejskich. Z Londynu wrócili tylko z jednym medalem. Brąz zdobył bokser wagi piórkowej Aleksy Antkiewicz, nazywany w środowisku sportowym „bombardierem z Wybrzeża” (w 1948 r. został w plebiscycie „Przeglądu Sportowego” wybrany najlepszy sportowcem w Polsce). Inicjatorem rywalizacji sportowców z Bałkan była Jugosławia, która po wojnie, wbrew Stalinowi forsowała koncepcję szerszej, niezależnej od ZSRR współpracy w regionie. Już w tym samym czasie doszło do sporu z ZSRR na tle interpretacji międzynarodowego komunizmu i „współpracy” z Moskwą, co ostatecznie doprowadziło do wykluczenia Jugosławii z Kominformu pod zarzutem „odchylenia nacjonalistycznego”. I choć Polska w tym sporze stanęła po stronie Kremla, to jednak wystartowała (tylko raz) w igrzyskach. Uzależnienie krajów satelickich od ZSRR było jednak na tyle duże, że zdecydowano o wycofaniu się z dalszego udziału w imprezie. Co ciekawe, formalnie wniosek o rezygnację zgłosiła federacja rumuńska wyjaśniając, że impreza miała charakter neutralny między rywalizacją sportowców z Zachodu ze sportowcami z ZSRR (także z pozostałych krajów demokracji ludowej). A zatem udział w niej krajów socjalistycznych uznano za bezcelowy z punktu widzenia politycznego i propagandowego ${ }^{15}$. W zastępstwie zorganizowano wspólne - środkowoeuropejskie zawody lekkoatletyczne w Bukareszcie. W imprezie tej z oczywistych względów nie wystąpiła już ekipa jugosłowiańska ${ }^{16}$. Choć udział w Igrzyskach Bałkańskich i Środkowoeuropejskich w opinii urzędników GUKF był ze wszechmiar pożądany, zarówno od strony sportowej, jak i propagandowej, to jednak zdecydowano, że priorytetem w sportowym ruchu międzynarodowym powinny być kontakty z ZSRR i krajami socjalistycznymi.

Analiza tzw. kalendarzy imprez sportowych, sporządzanych przez Wydział Spraw Zagranicznych GUKF potwierdza, że rzeczywiście kontakt ze sportowcami z Zachodu został w latach 1949-1953 znacznie ograniczony, niemal wyłącznie do udziału w zawodach rangi mistrzowskiej lub igrzysk olimpijskich. Pewnym wyjątkiem była rywalizacja z państwami skandynawskimi (głównie: Szwecją, Norwegią i Finlandią), a także Austrią, ewentualnie z klubami zachodnioeuropejskimi mającymi tradycje

15 AAN, GUKF, sygn. 67, Generalny Sekretariat Igrzysk Bałkańskich i Europy Środkowej, k. 1. Dokumentacja dot. Igrzysk Bałkańskich i Środkowoeuropejskich (pisma oficjalne, wnioski, korespondencja między organami zarządzającymi sportem w poszczególnych krajach i federacjami sportowymi, kalendarze imprez, sprawozdania, itd.), [w:] AAN, GUKF, sygn. 67.

16 Por. AAN, GUKF, sygn. 67, Generalny Sekretariat Igrzysk Bałkańskich i Europy Środkowej, k. 3 . 
lewicowe (przede wszystkim z Francji, Belgii, Holandii i Włoch). Tak czy inaczej w planach na 1949 r. i kolejne lata ustalono, że rywalami sportowców polskich powinni być przede wszystkim zawodnicy z ZSRR i pozostałych państw tzw. obozu. Sytuacja jednak nie była łatwa. Aby zorganizować zawody o randze międzynarodowej lub wyjechać na imprezę sportową poza granicę państwa trzeba było spełnić szereg procedur i warunków formalnych. Należy pamiętać, że choć organem bezpośrednio odpowiedzialnym na kontakty międzynarodowe był Wydział Spraw Zagranicznych GUKF (pomijam tutaj wewnętrzny obieg dokumentacji w GUKF), to decyzje formalne w tej sprawie podejmowało Ministerstwo Spraw Zagranicznych (dalej MSZ), ale nie samodzielne. Kluczowa rola należała do KC PZPR. Jeśli nie bezpośrednio, to przy akceptacji aktywu partyjnego. Dotyczyło to nie tylko wytypowania państw, $\mathrm{z}$ którymi można było rywalizować, ale również ustalenia personalnego składu drużyn (wraz z trenerami i ekipą techniczną) mających wyjechać za granicę. Selekcja obejmowała również dziennikarzy, korespondentów, fotoreporterów sportowych. Jesienią 1950 r. wyjazdy zagraniczne polskich sportowców zostały dodatkowo utrudnione. Powodem były przede wszystkim trudności finansowe, a właściwie dewizowe. Decyzją Prezesa Rady Ministrów (z 20 X 1950 r.) zmniejszono wydatki budżetowe na wyjazdy zagraniczne. Każdy wniosek o wyjazd (wraz z kosztorysem dewizowym) musiał uzyskać wcześniejszą zgodę ministra finansów i aprobatę odpowiedniego ministra resortowego (w przypadku sportu było to kierownictwo GUKF) ${ }^{17}$.

Analiza dokumentów urzędów sportowych i władz partyjnych skłania do kilku generalnych wniosków. Po pierwsze, co może dziwić, udział sportowców radzieckich w zawodach sportowych organizowanych przez Polskę nie był dla władz zadowalający. Doskonale oddają to słowa mjr. Freda Bettera, naczelnika Wydziału Spraw Zagranicznych GUKF. W jednym ze sprawozdań za rok 1948 pisał: „Bardzo zależało nam na kontakcie sportowym ze Związkiem Radzieckim. Kilkakrotnie drogą listową i drogą dyplomatyczną próbowaliśmy nawiązać ten kontakt, jednak mimo usilnych starań z naszej strony, próby te nie dały dotąd pozytywnego rezultatu" ${ }^{18}$. Większych efektów poza propagandowymi nie przynosiły również różnego rodzaju akcje „sportowe” mające podkreślić wagę sojuszu z ZSRR. Liczono, że deklarowany serwilizm zintensyfikuje wzajemne kontakty. Sztandarowym przykładem była cykliczna impreza pt. „Miesiąc Pogłębiania Przyjaźni Polsko-Radzieckiej”, w 1949 r.

\footnotetext{
17 AAN, GUKF, sygn. 132, Zarządzenie Prezesa Rady Ministrów, Warszawa 20 X 1950 r., k. $14-19$.
}

18 AAN, GUKF, sygn. 36, Sprawozdanie z prac Wydziału Zagranicznego GUKF w okresie od marca do września 1948 r., k. 29. 
zorganizowana pod autorskim hasłem Bolesława Bieruta: „Przyjaźń z ZSRR, pomoc ZSRR, przykład ZSRR - oto podstawowe źródło naszych zwycięstw”"19.

Najlepiej układały się relacje między sportowcami polskimi i czechosłowackimi, zarówno na szczeblu ogólnopaństwowym (reprezentacyjnym), jak i klubowym. $\mathrm{Na}$ drugim miejscu znajdowały się Węgry, następnie Bułgaria. Bilateralne kontakty sportowe ze sportowymi federacjami rumuńskimi, choć przebiegały względnie poprawnie, nie były nigdy intensywne. Najczęściej polscy sportowcy rywalizowali $\mathrm{z}$ rumuńskimi podczas imprez rangi mistrzowskiej.

Podczas zorganizowanych w Pradze I Mistrzostw Świata w Piłce Siatkowej Mężczyzn (10-18 IX 1949) ekipa Rumunii uplasowała się na dobrym czwartym miejscu, tuż za Bułgarią, Czechosłowacją i ZSRR (zwyciężyli we wszystkich rozgrywanych meczach, tracąc tylko jednego seta). Polska zajęła piąte miejsce. W bezpośrednim pojedynku drużyna polska uległa Rumunom w stosunku 1:3 $3^{20}$. Znacznie lepiej powiodło się polskim siatkarkom, które na równolegle zorganizowanych mistrzostwach Europy zdobyły brązowy medal, ulegając jedynie ekipom z Czechosłowacji i ZSRR. Rumunia znalazła się na czwartym miejscu przegrywając w bezpośrednim pojedynku z Polkami 0:3. Podczas II Mistrzostw Świata w Piłce Siatkowej Mężczyzn, które odbyły się w Moskwie (17-29 VIII 1952 r.), było już znacznie gorzej. Hegemonem pozostali nadal siatkarze radzieccy, Polacy zajęli dopiero 7, a Rumuni, podobnie jak w 1949 r. czwarte miejsce ${ }^{21}$. W kolejnych zorganizowanych w 1956 r. (III) Mistrzostwach Świata w Piłce Siatkowej Mężczyzn (w Paryżu) drużyna Rumunii osiągnęła swój największy sukces, zdobywając srebrny medal, Polska zajęła czwarte miejsce, choć w bezpośrednim pojedynku pokonała siatkarzy rumuńskich $3: 1^{22}$.

Na mistrzostwach Europy w koszykówce mężczyzn Polska wystąpiła dopiero w 1955 r. (turniej rozegrano na Węgrzech) i zajęła ostatecznie piąte miejsce, zaś Rumunia siódme, ale w bezpośrednim pojedynku Polacy ulegli Rumunom. W poprzednich dwóch imprezach rangi mistrzowskiej (w 1951 i 1953 r.) ekipa polska nie wzięła udziału, zaś Rumunii w 1951 r. wycofali się w ostatniej chwili (stąd przegrali

19 AAN, GUKF, sygn. 70, Pismo TPPR do GUKF, Warszawa 24 VIII 1949 r., k. 18-19; AAN, GUKF, sygn. 70, Udziat sportu polskiego w Miesiącu Przyjaźni Polsko-Radzieckiej, k. 20-21; AAN, GUKF, sygn. 70, Okólnik, k. 22; AAN, GUKF, sygn. 70, Zarządzenie organizacyjne, k. 29-30.

20 K. Mencer, Historia siatkówki - mistrzostwa świata, Katowice 2007, s. 7-12.

21 Ibidem, s. 13-18.

22 Ibidem, s. 19-28. 
wszystkie mecze walkowerem), a dwa lata później zajęli odległe trzynaste miejsce.

Areną rywalizacji polsko-rumuńskiej były również organizowane cyklicznie mistrzostwa Europy w boksie. Co prawda, w 1949 r. (Oslo) i 1951 r. (Mediolan) Rumuni, w odróżnieniu od zawodników polskich, nie odnieśli żadnych spektakularnych sukcesów, odpadając najczęściej już w walkach eliminacyjnych, to już w 1953 r., podczas zorganizowanych w Warszawie X Mistrzostw Europy, ekipa rumuńska zdobyła aż trzy brązowe medale (Ferencz Ambruș, Nicolae Linca, Nicolae Mindreanu). Był to zresztą najlepszy w pierwszych latach powojennych okres rozwoju rumuńskiego boksu. „Ikoną Karpat” był wówczas Nicolae Linca, złoty medalista igrzysk olimpijskich w Melbourne (1956 r.) i dwukrotny medalista mistrzostw Europy (w Warszawie w 1953 r. i Berlinie Zachodnim w 1955 r.). W warszawskiej imprezie startowało 117 uczestników z 19 państw, w tym dziesięciu reprezentantów Polski, którzy zdobyli łącznie dziewięć medali w niemal wszystkich kategoriach wagowych. Do historii przeszły zwycięstwa Zenona Stefaniuka nad Borisem Stiepanowem (ZSRR), Józefa Kruży nad Aleksanrem Zasuchinem (ZSRR), a zwłaszcza znonokautowanie dziesięciokrotnego mistrza Związku Radzieckiego w wadze półśredniej Siergieja Szczerbakowa (ZSRR) przez Zygmunta Chychłę ${ }^{23}$. Dla władz partyjnych o wiele ważniejszy niż zwycięstwa Polaków był jednak sukces krajów demokracji ludowej nad państwami kapitalistycznymi (zdobyły jedynie dwa złote krążki $)^{24}$.

Doskonałą okazją do międzynarodowej promocji haseł socjalizmu postępu i pokoju oraz solidarnej współpracy krajów demokracji ludowej był organizowany od 1948 r. (oficjalnie przez redakcje: „Głosu Ludu”, następnie „Trybuny Ludu”, „Rudé Právo”, od 1952 r. również przez organ SED „Neues Deutschland” oraz związki kolarskie Polski, Czechosłowacji, a następnie NRD) Międzynarodowy Bieg Kolarski Warszawa - Praga - Warszawa (od 1950 r. Wyścig Pokoju”) 25. Oprócz celów sportowych wyścig miał przede wszystkim zadania polityczne i ideologiczne. Do jego

23 Rok wcześniej, podczas Igrzysk Olimpijskich w Helsinkach Chychła również pokonał Szczerbakowa. Zob. J. Pindera, Pięściarze pokazali Rosjanom, kto jest najlepszy, „Rzeczpospolita”, 27 XI 2011.

24 Zob. szerzej: A. Pasko, Mistrzostwa Europy w Boksie w 1953 r. w ocenie władz partyjnych i sportowych, Teki Archiwalne 9 (31) (2006), s. 273-285.

25 Na temat Wyścigu Pokoju pisali m.in.: B. Tuszyński, Wyścig Pokoju 1948-988, Warszawa 1989; Idem, D. Marszałek, Wyścig Pokoju 1948-2001, Warszawa 2002; J. Ferenc, Sport w stuzbie polityki. Wyścig Pokoju 1948-1989, Warszawa 2008; A. Pasko, Wyścig Pokoju w dokumentach wtadz partyjnych i państwowych 1948-1980, Kraków 2009. 
organizacji włączono nie tylko związki kolarskie, zrzeszenia sportowe, ale przede wszystkim KC PZPR, komitety wojewódzkie, powiatowe i miejskie partii, organizacje młodzieżowe i społeczne, prasę, szkoły (odwoływano zajęcia w szkołach położonych co najmniej $10 \mathrm{~km}$ od trasy wyścigu), rady narodowe. Nie można również zapominać o tym, że kolarstwo było dyscypliną zespołową, gdzie kolektyw pracował na zwycięstwo indywidualne zawodnika, co doskonale uzasadniało model sportu socjalistycznego. W tych zawodach, w interesującym nas okresie polscy sportowcy odnieśli znaczące sukcesy. Wygrywali corocznie nie tylko kolejne etapy wyścigu, ale zajmowali również wysokie miejsca w klasyfikacji generalnej. Do historii przeszło już legendarne zwycięstwo Stanisława Królaka w 1956 r. W przypadku kolarzy rumuńskich nie można było mówić o spektakularnych sukcesach. Start w Wyścigu Pokoju dla drużyny rumuńskiej wynikał raczej z poczucia obowiązku promocji haseł walki o pokój i socjalizm. Rywalizacja czysto sportowa schodziła tutaj na dalszy plan. Zdecydowanie najlepiej Rumunia wypadła w inauguracyjnym wyścigu w 1948 r. Trzeba jednak zaznaczyć, że startowało wówczas zaledwie 65 kolarzy z kilku krajów. Nie zgłoszono żadnej ekipy z zachodniej Europy. Tak, czy inaczej, drużyna rumuńska, która co prawda zajęła ostatnie, dziewiąte miejsce (w klasyfikacji drużynowej) zaznaczyła swoja obecność na trasie wyścigu. Dymitru Pantazescu zajął trzecie miejsce na I etapie, Traian Chicomban na V etapie, a etap II zwyciężył Marin Nicolescu (na III etapie zajął trzecią lokatę) - zdecydowanie najlepszy kolarz rumuński podczas tych zawodów (nie uplasował się jednak nawet w pierwszej dziesiątce klasyfikacji generalnej). Podczas kolejnych edycji wyścigu, kiedy dołączyły do niego również drużyny z Europy Zachodniej (np. Francja, Dania, Holandia, Anglia) Rumuni pozostawali tłem dla pozostałych drużyn, nie licząc premiowanych (pierwsze dziesięć) miejsc w poszczególnych etapach. Do 1956 r. żaden rumuński kolarz nie znalazł się w czołówce klasyfikacji generalnej Wyścigu Pokoju. Zaś w klasyfikacji generalnej (drużynowej) Rumuni zajmowali zazwyczaj odległe miejsca, najgorsze spośród krajów demokracji ludowej.

Kolejną formą kooperacji polsko-rumuńskiej sportowej były relacje bilateralne. Wydarzeniem o międzynarodowej randze było otwarcie w 1948 r. stadionu lekkoatletycznego w Bukareszcie. Na uroczystość oprócz polskich lekkoatletów (łącznie 28 osób) zaproszono również delegatów GUKF. W specjalnie sporządzonym sprawozdaniu, delegat GUKF, tow. Antoni Miller zwracał szczególną uwagę na panującą w Rumunii atmosferę życzliwości i serdeczności, dobrą oprawę propagandową imprezy, przyzwoite warunki aprowizacyjne. Szczególnie imponujący był sam stadion mieszczący ponad 50 tys. kibiców, odbudowany w zaledwie 80 dni przez 
ochotników, przodowników pracy i młodzieżowe organizacje. Pod względem czysto sportowym można było mówić o pełnym sukcesie reprezentacji Polski, zwłaszcza, że w Bukareszcie pojawili się zawodnicy światowej klasy z legendarnym Emilem Zátopkiem, znakomitym czechosłowackim długodystansowcem, czterokrotnym medalistą olimpijskim. Polacy zwyciężyli w trzech dyscyplinach, w pozostałych albo stawali na podium, albo uplasowali się w czołówce. Większych wątpliwości nie budziła również strona oficjalna imprezy, przemówienia dygnitarzy partyjnych, włodarzy sportu z Rumunii, Węgier, Czechosłowacji i Polski. Wszyscy zgodnie zwracali uwagę na konieczność dalszej współpracy bratnich krajów socjalistycznych, przyjacielskiej rywalizacji i współpracy. We wnioskach końcowych Miller notował: „Niewątpliwie ten pierwszy w szerszym znaczeniu kontakt z lekkoatletyką państw ludowo-demokratycznych i zadzierzgnięte więzy koleżeństwa przyczyniają się do znacznego ożywienia międzynarodowego kalendarza lekkoatletyki polskiej, a tym samym do jej rozwoju i podniesienia poziomu. Z punktu widzenia politycznego najcenniejszy jest fakt, że wyprawa bukaresztańska jest niewątpliwie nowym przyczynkiem dla dalszego zacieśniania poprzez sport stosunków z tymi właśnie republikami demokratyczno-ludowymi, które są nam najbliższe ideologicznie"26.

$\mathrm{Na}$ dalszą kooperację polsko-rumuńską nie trzeba było długo czekać. Już we wrześniu 1948 r. w Bukareszcie odbył się pierwszy po wojnie oficjalny dwumecz tenisa ziemnego. Od strony czysto sportowej rywalizacja była bardzo wyrównana i stała na wysokim poziomie. Powody do optymizmu budziła zwłaszcza gra Władysława Skoneckiego i Jadwigi Jędrzejowskiej, finalistki Wimbledonu w grze pojedynczej z $1937 \mathrm{r}$. i finalistki mistrzostw USA w grze pojedynczej z tego samego roku. Za przegraną drużyny polskiej obarczano zwłaszcza stronę rumuńską, która kilkakrotnie zmieniała plany turnieju i zbyt późno poinformowała polską federację o ostatecznym terminie. Dodatkowo zawodnicy polscy po nużącej dwudniowej podróży autobusem do Budapesztu, musieli spędzić noc na tamtejszym dworcu, aby udać się do Rumunii. Na kilka godzin przed meczem, jak informował sprawozdawca GUKF byli już bardzo zmęczeni i poddenerwowani, co miało wpływ na postawę na korcie ${ }^{27}$. Bez zarzutu była natomiast organizacja spotkania, miejsce zakwaterowania, posiłki, imprezy towarzyszące, spotkanie z przedstawicielami polskiej ambasady i podarki

26 AAN, GUKF, sygn. 68, Sprawozdanie $z$ podróży jako delegat GUKF wraz z lekkoatletyczna reprezentacją Polski do Rumunii na igrzyska z okazji inauguracji "stadionu Republiki” $w$ Bukareszcie, k. 72 .

27 AAN, GUKF, sygn. 68, Sprawozdanie z meczu Rumunia - Polska rozegranego w Bukareszcie $w$ dn. 15-20 V 1948 r., k. 168-171. 
od strony rumuńskiej - kosze z winem i wiązanki kwiatów. Kolejny dwumecz rozegrano rok później, w 1949 r. Polska ponownie przegrała, ale ostateczny wynik nie był najważniejszy. Uwagę korespondenta sportowego - redaktora Bohdana Tomaszewskiego zwróciło „kompromitujące” zachowanie Władysława Skoneckiego, który najpierw podczas pojedynku w grze podwójnej odnosił się niewłaściwie do swojego partnera, a później po konflikcie w sędzią liniowym przestał w ogóle odbijać piłki. Dziennikarze prasy sportowej nie zostawili na Skoneckim, najlepszym wówczas polskim tenisiście, suchej nitki. Oskarżano go o brak profesjonalizmu, nieumiejętność pracy w kolektywie i brak odpowiednio wyrobionej świadomości ideowej ${ }^{28}$. Polscy tenisiści wzięli również udział w rozgrywanych we wrześniu $1949 \mathrm{r}$. międzynarodowych zawodach o mistrzostwo Rumunii, spisali się jednak poniżej oczekiwań. Młodym Polakom zabrakło przede wszystkim rutyny, doświadczenia i kondycji - czytamy w sprawozdaniu GUKF ${ }^{29}$. Pełnym sukcesem zakończyły się natomiast rozgrywane w Rumunii, we wrześniu 1949 r. zawody pływackie. Antoni Rybakowski osiągnął w wyścigu stylem motylkowym na 200 metrów najlepszy powojenny wynik, ustanawiając przy tym rekord kraju. Zgodnie uznano, że wygrane przez polskich pływaków zawody stały na wysokim poziomie ${ }^{30}$.

Jednym z najważniejszych wydarzeń w kontaktach sportowych między Polską a Rumunią był piłkarski mecz międzypaństwowy rozegrany w Bukareszcie w maju 1949 r. ${ }^{31}$ W stolicy Rumunii został on rozreklamowany jako jedno z najważniejszych i największych wydarzeń w historii tamtejszego futbolu. Sprawozdawca z zawodów z ramienia GUKF, a zarazem kierownik ekspedycji do Bukaresztu ubolewał nad faktem, że strona rumuńska nie była przygotowana do przyjęcia polskiej drużyny. Nie zorganizowano dodatkowych zajęć w wolnym czasie, imprez towarzyszących jak to zazwyczaj było praktykowane, poza krótką przechadzką po centrum mia-

28 AAN, GUKF sygn. 59, Przegląd Prasy nr 10, k. 33-34; AAN, GUKF sygn. 59, Przegląd Prasy $n$ r 12, k. 41; Kompromitacja, „Kurier Codzienny”, 21 V 1949. Skonecki pomimo incydentu w Bukareszcie, ze względu na swoje czysto sportowe umiejętności był ceniony przez aparat partyjny i włodarzy zarządzających sportem. W 1951 r. po meczu ze Szwajcarią Skonecki nie wrócił do kraju. Błyskawicznie z bohatera stał się „renegatem” i „zdrajcą”. Por. A. Pasko, Sport wyczynowy, s. 189.

29 AAN GUKF, sygn. 69, Sprawozdanie z Międzynarodowych Mistrzostw Rumunii w Bukareszcie, k. 286.

30 AAN, GUKF, sygn. 59, Przegląd Prasy nr 28, k. 66.

31 Pierwsze oficjalne mecze między Polską a Rumunią rozegrano w 1947. Pierwszy polscy piłkarze przegrali (1:2) a drugi zremisowali (0:0). 
sta. Ponadto, jak czytamy w sprawozdaniu, Polacy mieli problem z dziennikarzami i kibicami rumuńskimi. Otoczyli oni hotel, w którym przebywali polscy piłkarze. Również od strony sportowej zarówno odprawa przedmeczowa, jak i samo już spotkanie rodziły wiele wątpliwości. Rumuni mieli zabiegać o większą, niż ustalono wcześniej liczbę zmian podczas meczu. Już podczas zawodów stronniczością miał się wykazać węgierski sędzia, który nie zwracał uwagi na ostrą grę Rumunów (na początku spotkania po brutalnym faulu murawę opuścił Gerard Cieślik) i nie uznał prawidłowo strzelonej bramki przez Polaków. Co oczywiste, większość publiczności dopingowała gospodarzy. Ale - czytamy dalej - polscy piłkarze mogli liczyć na doping obecnych na meczu żołnierzy Armii Czerwonej. Dodatkowy zgrzyt pojawił się na wieczornym bankiecie, na który nie zaproszono polskiego ambasadora ${ }^{32}$.

W maju 1949 r. do Bukaresztu na oficjalny mecz międzypaństwowy udała się także reprezentacja polskich koszykarzy. Polacy zostali przyjęci bardzo życzliwie. Już na granicy powitała ich specjalna delegacja partyjno-rządowa, członkowie rumuńskiej federacji piłki koszykowej, przedstawiciel ambasady RP, dziennikarze, fotoreporterzy i sportowcy rumuńscy. Polaków zakwaterowano w reprezentacyjnym, ekskluzywnym hotelu „Ambasador”, zapewniono szereg atrakcji, jak zwiedzanie miasta, muzeów, koncerty, wystawy. Do wizyty polskich koszykarzy przygotowała się również rumuńska prowincja, zwłaszcza te miasteczka, gdzie Polacy mieli do dyspozycji bazę treningową. Witano ich z ogromną życzliwością. Niemal wszędzie pojawiała się młodzież, przodownicy pracy, weterani wojenni, orkiestry, delegacje urzędów i zakładów pracy wyposażone w tysiące biało-czerwonych chorągiewek i dziesiątki transparentów. Pobyt polskich sportowców w Bukareszcie miał jednak swoją drugą, mniej oficjalną stronę. Sprawozdawca z ramienia Polskiego Związku Koszykówki, Siatkówki i Szczypiorniaka zwrócił uwagę, że ubiór i wyposażenie polskich koszykarzy daleko odbiegały od europejskich standardów. Dresy były podarte i podniszczone, niektórzy zawodnicy nie mieli również odpowiedniego obuwia. Kilku grało w pożyczonych od Rumunów tenisówkach, a jeden w skórzanych pantoflach na cienkiej podeszwie, całkowicie nieodpowiednich do gry. Sportowo, (ale nie tylko) Rumuni okazali się lepsi i wygrali nieznacznie z koszykarzami polskimi 27: $41^{33}$.

32 AAN, GUKF, sygn. 69, Sprawozdanie z wyjazdu na zawody pitki nożnej Polska - Rumunia $w$ Bukareszcie $w$ dn. 8 V 1949 r., k. 119-120.

33 AAN, GUKF, sygn. 69, Sprawozdanie $z$ pobytu koszykarzy polskich $w$ Rumunii $w$ dniach 11 - 24 V 1949 r., k. 126-127. 
Na przełomie lipca i sierpnia 1949 r. w Warszawie gościła rumuńska reprezentacja lekkoatletyczna. Same zawody przebiegły w sportowej atmosferze, bez żadnych incydentów i zakłóceń. Organizatorzy starali się również zapewnić gościom jak najwięcej atrakcji. Rumuni zwiedzili stare miasto, nowo wybudowaną Trasę W-Z, nowoczesne, socrealistyczne budynki mieszkalne i sportowe (hale, baseny, stadiony). Do największego incydentu doszło podczas zwiedzania starówki, kiedy zawodników rumuńskich zaczęli zaczepiać przechodnie, pytając, czy są Cyganami. Wywołało to zamieszanie, zakończone dopiero oficjalnymi przeprosinami ze strony polskiej. Anna Bober - zastępca dyrektora Stołecznego Urzędu Kultury Fizycznej zwróciła uwagę na jeszcze jeden fakt, z ideologicznego punktu widzenia istotny. Mianowicie w zorganizowanych pogadankach ideologicznych zawodnicy rumuńscy mieli się wykazać dużą świadomością klasową, dojrzałością ideologiczną i dyscypliną. Posiadali również znaczną wiedzę na temat przebiegu wojny i okupacji na ziemiach polskich. Ten pozytywny z punktu polityczno-propagandowego punktu widzenia obraz zaburzały nieco „drobne” zdarzenia, jak podejmowane przez sportowców rumuńskich próby zakupu dewiz, kupna kakao i czekolady za pieniądze przeznaczone na diety, niezbyt pochlebne wypowiedzi na temat polskiej gospodarki czy wartości złotego. Rumuńscy zawodnicy mieli również narzekać na niestrawne i kaloryczne posiłki, jakie im zaserwowano w Warszawie ${ }^{34}$.

W 1949 r. sportowcy polscy i rumuńscy rywalizowali jeszcze w międzynarodowych zawodach szachowych w Sopocie (czwórmecz: Polska, Bułgaria, Rumunia, Węgry); meczu piłki nożnej (drugich drużyn); międzypaństwowym spotkaniu koszykówki mężczyzn i kobiet; wyścigach motocyklowych w Bukareszcie, międzynarodowych zawodach lekkoatletycznych w Pradze, dwumeczu szermierczym w Warszawie, w mistrzostwach Europy w wioślarstwie (Amsterdam); międzynarodowym turnieju siatkówki kobiet (Bukareszt) ${ }^{35}$. W zaplanowanym na rok później kalendarzu imprez przewidywano udział sportowców Polski i Rumuni w kilku znaczących, międzynarodowych imprezach, jak na przykład: zawody wioślarskie krajów demokracji ludowej; międzynarodowy turniej szachowy (Brno); międzynarodowe zawody jeździeckie krajów socjalistycznych; międzynarodowy bieg kolarski w Bułgarii, turniej bokserski, międzynarodowy turniej w hokeju na lodzie (Katowice);

34 AAN, GUKF, sygn. 69, Sprawozdanie z pobytu rumuńskiej drużyny lekkoatletycznej $w d n$. 30-31 VII i 1 VIII 1949 r. w Warszawie, k. 179-180.

35 AAN, GUKF, sygn. 70, Terminarz imprez międzypaństwowych i międzynarodowych na rok 1949, k. 168-176; AAN, GUKF, sygn. 71, Sprawozdanie cyfrowe za lata 1946-1947 i planowane na rok 1949, bps. 
międzynarodowy wyścig uliczny (samochodowy) o „Złoty Kask Poznania”, turniej tenisa stołowego, turniej tenisa ziemnego (Karlowe Vary) czy zawody strzeleckie ${ }^{36}$.

W kolejnych latach liczba wspólnych imprez i zawodów nie uległa zasadniczym zmianom. Utrzymywała się na podobnym poziomie. Niemal cyklicznie odbywały się turnieje w grach zespołowych, zawody tenisowe czy biegi kolarskie. Zdarzały się jednak sytuacje, kiedy to zaplanowane w kalendarzu na kolejny rok imprezy nie doszly do skutku. Decydowały o tym różne względy. Niekiedy zwyczajnie organizatorzy wycofywali się z wcześniejszych planów, np. w związku z pobytem w tym samym czasie sportowców na obozach przygotowawczych przed mistrzostwami Europy bądź świata. Nierzadko decydowały o tym również względy finansowe. Zdarzały się również sytuacje, że propozycje organizacji imprez sportowych zgłaszało MSZ, bez wcześniejszych konsultacji z GUKF. Pojawiająca się kolizja terminów zmuszała GUKF do wycofania się z wcześniejszych planów. Zatem tzw. kalendarz imprez sportowych, choć najczęściej bardzo doprecyzowany, był zmienny, uzależniony od stanowiska innych organów współdecydujących o sporcie wyczynowym i od deficytów finansowych. Świadczyło to także o tym, że GUKF miał niewielki stopień samodzielności, a decyzje o międzynarodowych kontaktach sportowych zapadały w innych organach, jak MSZ czy KC PZPR (najczęściej w Wydziale Propagandy Masowej KC PZPR, od 1953 r. Wydziale Propagandy i Agitacji KC PZPR lub w Sekretariacie KC PZPR). Trudno było sobie przecież wyobrazić, aby organizacja dużej międzynarodowej imprezy sportowej odbyła się poza wiedzą politbiura czy też organów bezpieczeństwa publicznego. Należało zadbać nie tylko o jej przebieg od strony sportowej, ale i polityczno-propagandowej, zagwarantować bezpieczeństwo wewnętrzne i zewnętrzne (kontakty zawodników z przedstawicielami obcych ambasad, dyplomatami, dziennikarzami z krajów zachodnioeuropejskich). Od $1950 \mathrm{r}$. pojawiały się przypadki tzw. „imprez niepożądanych” ze względów politycznych lub ideologicznych. Kwalifikacji dokonywał wówczas albo Wydział Zagraniczny KC PZPR albo Wydział Propagandy Masowej KC PZPR. Patrząc z nieco innej perspektywy swoisty chaos decyzyjny i kompetencyjny był też efektem nadmiernego centralizmu i rozbudowanej biurokracji, co zresztą charakteryzowało niemal wszystkie dziedziny życia w PRL.

W latach 1952-1954 liczba odwołanych imprez międzynarodowych znacznie wzrosła. Jak wówczas tłumaczono, należało skoncentrować wysiłki na celu nad-

36 AAN, GUKF, sygn. 70, Międzynarodowy kalendarz sportowy na rok 1950, k. 179-180; AAN, GUKF, sygn. 70, Notatka w sprawach międzynarodowych, k. 226-228. 
rzędnym: umasowieniu sportu i rekreacji oraz nadaniu im ideologicznych podstaw. Troska o to, aby polscy sportowcy byli obecni na międzynarodowych arenach, schodziła na dalszy plan. Dopiero z początkiem 1955 r. liczba przedsięwzięć sportowych o międzynarodowej randze wzrosła, co więcej, przekraczała nawet wcześniej zaplanowaną w kalendarzach sportowych. Zmalała również ingerencja czynników partyjnych w organizacje imprez lub udział sportowców polskich w zawodach poza granicami kraju. Był to, jak można sądzić, efekt politycznej odwilży.

Polsko-rumuńska międzynarodowa kooperacja sportowa w latach 1948-1953 nigdy nie była tak intensywna jak choćby współpraca ze sportowymi federacjami z Czechosłowacji czy Węgier. Stanowiła jednak stały element sportowej polityki międzynarodowej, zwłaszcza jeśli chodzi o relacje z krajami demokracji ludowej. Dopiero po 1956 r., a przede wszystkim w latach sześćdziesiątych i siedemdziesiątych proces ten ewoluował i Rumunia stała się jednym z najważniejszych partnerów PRL w międzynarodowych stosunkach sportowych.

Nadesłany: 7 IV 2019

Nadesłany po poprawkach recenzyjnych: 3 VII 2019

Zaakceptowany: 4 XII 2019

Dr hab. prof. US Tomasz Sikorski

ORCID 0000-0002-3090-0793

Instytut Historii i Stosunków Międzynarodowych

Wydział Humanistyczny US

Uniwersytet Szczeciński

ul. Krakowska 71-79

71-017 Szczecin

email: t.sikorski@poczta.fm

Dr hab. prof. US Urszula Kozłowska

ORCID 0000-0001-5444-5847

Instytut Socjologii

Wydział Humanistyczny US

Uniwersytet Szczeciński

ul. Krakowska 71-79

71-017 Szczecin

email: urszula.kozlowska@usz.edu.pl 


\section{Cooperation in competitive sport in the Eastern Bloc - an example of Polish-Romanian contacts (1948-1953)}

Polish-Romanian sports contacts after WWII have not attracted much attention on the part of academics. This article includes an analysis of the following (research) issues: 1) organizational, institutional and ideological changes in sport in Poland and the Eastern Bloc countries after WWII; 2) implementation of the Soviet model of organising sport and physical culture in the Eastern Bloc; 3) Polish - Romanian sports contacts in 1948-1953; 4) the ideological, propaganda-related, institutional and purely sport-related dimension of PolishRomanian sports contacts; 5) the successes of Polish and Romanian sports federations in 1948-1953; 6) the difficulties and barriers to sports cooperation. Polish-Romanian sports contacts in the time of Stalinism were never intense; only after 1956 did Romania become one of Poland's most important partners in international sports relations.

Translated by: Ewa Dratwa 